\title{
Case Study of Effects of Mineral N Fertilization Amounts on Water Productivity in Rainfed Winter Rapeseed Cultivation on a Sandy Soil in Brandenburg (Germany) over Three Years
}

\author{
Katrin Drastig ${ }^{1, *} \mathbb{(}$, Ulrich Kreidenweis ${ }^{1}\left(\mathbb{D}\right.$, Andreas Meyer-Aurich ${ }^{1}\left(\mathbb{D}\right.$, Christian Ammon $^{1}(\mathbb{D}$ and \\ Annette Prochnow 1,2 \\ 1 Leibniz Institute for Agricultural Engineering and Bioeconomy (ATB), Max-Eyth-Allee 100, \\ 14469 Potsdam, Germany; ukreidenweis@atb-potsdam.de (U.K.); ameyer-aurich@atb-potsdam.de (A.M.-A.); \\ cammon@atb-potsdam.de (C.A.); aprochnow@atb-potsdam.de (A.P.) \\ 2 Faculty of Life Sciences, Humboldt-University of Berlin, Hinter der Reinhardtstr. 8-18, 10115 Berlin, Germany \\ * Correspondence: kdrastig@atb-potsdam.de; Tel.: +49-331-5699-218
}

\section{check for} updates

Citation: Drastig, K.; Kreidenweis, U.; Meyer-Aurich, A.; Ammon, C.; Prochnow, A. Case Study of Effects of Mineral N Fertilization Amounts on Water Productivity in Rainfed Winter Rapeseed Cultivation on a Sandy Soil in Brandenburg (Germany) over Three Years. Water 2021, 13, 1958. https://doi.org/10.3390/w13141958

Academic Editor: Teresa Afonso do Paço

Received: 23 April 2021

Accepted: 1 July 2021

Published: 16 July 2021

Publisher's Note: MDPI stays neutral with regard to jurisdictional claims in published maps and institutional affiliations.

Copyright: (c) 2021 by the authors. Licensee MDPI, Basel, Switzerland. This article is an open access article distributed under the terms and conditions of the Creative Commons Attribution (CC BY) license (https:// creativecommons.org/licenses/by/ $4.0 /)$.

\begin{abstract}
Detailed knowledge about farm management practices and related hydrological processes on water productivity is required to substantially increase the productivity of precipitation water use in agriculture. With this in mind, the effect of the nitrogen $(\mathrm{N})$ fertilization level on water productivity of winter oilseed rape (Brassica napus L.) was analyzed using a modeling approach and field measurements. In this first study of interception loss and water productivity in winter oilseed rape, the crop was cultivated in a field experiment on a sandy soil in Brandenburg (Germany) under five nitrogen fertilization treatments with $0,60,120,180$, and $240 \mathrm{~kg}$ mineral $\mathrm{N} \mathrm{ha}^{-1} \mathrm{a}^{-1}$. Based on data from three vegetation periods the water flows and the mass-based water productivity of seeds were calculated on a daily basis with the AgroHyd Farmmodel modeling software. As recommended from the recently developed guidelines of the FAO on water use in agriculture, the method water productivity was applied and uncertainties associated with the calculations were assessed. Economic profit-based water productivity $\left(\mathrm{WP}_{\text {profit }}\right)$ was calculated considering the costs of fertilization and the optimal level of $\mathrm{N}$ fertilization, which was determined based on a quadratic crop yield response function. Mean water productivity of seeds varied from $1.16 \mathrm{~kg} \mathrm{~m}^{-3}$ for the unfertilized control sample to $2.00 \mathrm{~kg} \mathrm{~m}^{-3}$ under the highest fertilization rate. $\mathrm{N}$ fertilization had a clearly positive effect on $\mathrm{WP}_{\text {profit }}$. However, fertilizer application rates above $120 \mathrm{~kg} \mathrm{~N} \mathrm{ha}^{-1} \mathrm{a}^{-1}$ led to only marginal increases in yields. Water productivity of seeds under the highest fertilization rate was only insignificantly higher than under medium application rates. The optimum $\mathrm{N}$ level for the maximal $\mathrm{WP}_{\text {profit }}$ identified here was higher with $216 \mathrm{~kg} \mathrm{~N} \mathrm{ha}^{-1} \mathrm{a}^{-1}$. The conclusion is that further research is needed to investigate the interaction between fertilization and other farm management practices.
\end{abstract}

Keywords: winter oilseed rape; water use; nitrogen; water-storage capacity; AgroHyd Farmmodel

\section{Introduction}

Water resources are an essential basis for agricultural production. Water productivity in plant production and in livestock farming will need to be increased to meet the food demands of a growing world population under climate change [1]. It became obvious, particularly in the very recent years of 2018, 2019, and 2020, that even the northern parts of Central Europe with their mainly moist climate will be challenged by long-term periods without sufficient precipitation during summer months in future. Due to the intense drought in 2018 with a long dry and hot period during the growing season, most parts of Germany experienced serious consequences, including in forestry and agriculture. Those extreme conditions continued in 2019 when Germany experienced heat waves at an intensity not seen before in June and July. In July 2019, temperatures exceeded the $40{ }^{\circ} \mathrm{C}$ 
threshold on three consecutive days at many of the measuring stations in the western part of Germany with a new temperature record of more than $42^{\circ} \mathrm{C}$. The drought continued until the end of 2019 [2]. With an average annual precipitation of about $558 \mathrm{~mm}$ [2], the state of Brandenburg, Germany, is considered to be one of the driest regions, not just of Germany, but also of the European continent (Table 1). Consequently, the assessment of the influence of different farming practices on water productivity (i.e., "more crop per drop") is not any longer an academic fancy but of high practical relevance. Brandenburg is dominated by sandy soils with rather low water-storage capacity. Local sites in Brandenburg might lose their productivity without the use of irrigation, should they become subject to more frequent and long-lasting droughts [3]. It has to be taken into account that the effects of extremely dry years such as 1976, 2002, and 2018 cannot be managed better solely with improved use of precipitation water, since during long-lasting and successive dry periods the availability of groundwater and surface water for irrigation purposes may also decline. Hence, conflicts over the limited surface water resources, sinking groundwater tables, as well as decreasing water quality are expected to rise [4]. This brings precipitation water further into the focus. It is useful to think of rain as the ultimate source of water for all agroecosystems [5]. Furthermore, farm management practices increasing the productivity of precipitation water in agriculture improve the productivity of irrigation water as well, because the processes of water storage are comparable. For example, a higher humus concentration increases the potential water storage in the soil [3] regardless of whether the water originates from precipitation or irrigation water.

Table 1. Meteorological characteristics of the study site. (a) Long-term means (1985-2015) of annual precipitation, air temperature ( $2 \mathrm{~m}$ ), and wind speed; and annual values in the experimental years. (b) Harvest dates of the winter oilseed rape and precipitation in the vegetation and fallow period.

\begin{tabular}{|c|c|c|c|c|}
\hline (a) & Year & Precipitation $\left(\mathrm{mm} \mathrm{a}^{-1}\right)$ & Air Temperature $\left({ }^{\circ} \mathrm{C}\right)$ & Wind Speed $\left(\mathrm{m} \mathrm{s}^{-1}\right)$ \\
\hline & 1985-2015 mean $( \pm S D)$ & $509( \pm 130)$ & $8.7( \pm 3.2)$ & $3.2( \pm 0.3)$ \\
\hline & 2012 & 501 & 9.6 & 3.6 \\
\hline & 2013 & 615 & 9.4 & 3.2 \\
\hline & 2014 & 482 & 10.9 & 3.1 \\
\hline & 2015 & 570 & 10.6 & 3.5 \\
\hline \multirow[t]{4}{*}{ (b) } & Harvest Date of Previous Crop & Harvest Date of Rapeseed & $\begin{array}{c}\text { Duration Vegetation + Fallow } \\
\text { Period (d) }\end{array}$ & $\begin{array}{c}\text { Precipitation in Vegetation }+ \\
\text { Fallow Period }(\mathrm{mm})\end{array}$ \\
\hline & 30 July 2012 & 1 August 2013 & 367 & 550 \\
\hline & 16 July 2013 & 16 July 2014 & 365 & 562 \\
\hline & 15 July 2014 & 28 July 2015 & 378 & 503 \\
\hline
\end{tabular}

Generally, water productivity is defined as the relation of agricultural output to input of water [6]. Higher water productivity means that more products and services can be produced with the same amount of water or that the same number of products and services can be generated with less water. The concept of water productivity is "a key performance indicator of water use in food production systems" [7-9] through the assessment of the effects of farm management practices. Traditionally, a definition of water use efficiency has been commonly used in the assessment of water use in agricultural production systems. However, water use efficiency (WUE) and water productivity (WP) are two different concepts. In general, WUE refers to the ratio (or percentage) of water that is productively consumed by a plant [10]. For example, if the WUE is $80 \%$, it means that, for example, 8 of $10 \mathrm{~mm}$ of water available to a crop are used by plant root water uptake and the remaining $2 \mathrm{~mm}$ are drained below the root zone or lost due to unproductive soil evaporation. As noted previously, WP refers to the ratio of output generated to water consumed. For example, WP is $50 \mathrm{~kg} / \mathrm{m}^{3}$, if $50 \mathrm{~kg}$ grain is produced per $1 \mathrm{~m}^{3}$ of water consumed [10]. Moreover, WP provides a conceptual framework that can be defined by using different terms for the numerator (e.g., biomass, harvestable yield, economic value) and denominator (e.g., transpiration, evapotranspiration, irrigation, water inflow) [11]. Respectively, the framework "Water use indicators at farm scale" was developed to assist farmers in better 
understanding the water flows on their farms and in optimizing water use by adapting agronomic practices and farm management [12]. The method only includes transpiration water as the fraction of precipitation contributing to plant biomass generation [12-15]. Farming practices that substantially raise water productivity in plant production have been identified $[2,16]$.

Farming practices may influence the specific productivity under given site-specific climate, soil and plant conditions. The water fluxes at field scale, i.e., stemflow, throughfall, infiltration, percolation, runoff, soil moisture, capillary rise, root water uptake, interception, evaporation, and transpiration, determine biomass production to a large extent. The most relevant management practices to raise the productivity of precipitation water are: soil tillage (roughening of the surface/fallowing of crusts, no-till); humus conservation (application of organic matter; mulching; turning under of crop residues); fertilizing (organic-mineral fertilization, e.g., [17]; mineral fertilization; sufficient $\mathrm{N}-$, $\mathrm{P}-$, K- supply; timing, e.g., [18]); crop rotation (optimizing of crop rotation and intermediate crop, e.g., [19]; plant protection); seeding (seed-bed preparation; high crop density; seeding date; frost protection); breeding (drought-tolerant varieties; varieties with high transpiration efficiency, e.g., [20]; coverage, e.g., [21]); wind protection; cultivation of legumes; increasing activity of microorganisms; and irrigation with harvested water (e.g., [17]).

In this study, the practice of farm fertilization was investigated. For winter rapeseed cultivation in Brandenburg, optimal $\mathrm{N}$ fertilizer rates are calculated according to the plant needs and available $\mathrm{N}$ from the soil [22]. The current German governmental fertilizer regulation Düngeverordnung $(D \ddot{u} V)$ restricts the $\mathrm{N}$ fertilizer supply in Germany according to crop yields of previous years to avoid nutrient discharge into the environment. These criteria pertain to matters such as determining fertilizer needs, the timing of fertilizer application, buffer strips for surface waterbodies, and rules concerning ammonia emission abatement. The Düngeverordnung regulation also implements Council Directive 91/676/EEC into German law. The general site-specific $\mathrm{N}$ fertilization amount of rapeseed in Brandenburg is $150-170 \mathrm{~kg}$ mineral $\mathrm{N} \mathrm{ha}^{-1} \mathrm{a}^{-1}$ [22], depending as well strongly on yield expectations and nitrogen reserves in the soil. For winter rapeseed, often more than $120 \mathrm{~kg}$ mineral $\mathrm{N} \mathrm{ha}^{-1} \mathrm{a}^{-1}$ need to be applied to reach the economical optimum [23].

Evaporation from interception at five treatments of $\mathrm{N}$ fertilization in Germany over three vegetation periods were compared in a previous study to understand the influence of $\mathrm{N}$ fertilization on rainfall interception loss [24]. Field measurements of throughfall in winter oilseed rape on a sandy soil were used to determine the evaporation from interception. The observations were interpreted for different treatments and development stages. A clear increase in evaporation from interception reflecting the increasing $\mathrm{N}$ fertilization treatments was found. The leaf area index (LAI) in winter oilseed rape increased with increasing amounts of $\mathrm{N}$ fertilization from $0 \mathrm{~kg}$ mineral $\mathrm{N} \mathrm{ha}^{-1} \mathrm{a}^{-1}$ (control) to $240 \mathrm{~kg}$ mineral $\mathrm{N} \mathrm{ha}^{-1} \mathrm{a}^{-1}$ [24]. The results [25] showed as well that higher $\mathrm{N}$ fertilization levels had a favorable effect on LAI of rapeseed mustard. The same authors found highly significant correlations between seed yield vs. LAI, leaf area duration, and crop growth rate. Fertilization up to $120 \mathrm{~kg}$ mineral $\mathrm{N} \mathrm{ha}^{-1} \mathrm{a}^{-1}$ was found beneficial in enhancing growth and yield of rapeseed mustard. Another study [26] found that increasing $\mathrm{N}$ fertilizer application rates $\left(0,60,120,180,240\right.$, and $\left.300 \mathrm{~kg}_{\text {mineral }} \mathrm{N} \mathrm{ha}^{-1} \mathrm{a}^{-1}\right)$ remarkably increased LAI, aboveground dry matter, seed yield, ET, and WP of winter oilseed rape under two different cultivation patterns.

The objectives of this investigation of winter oilseed rape (Brassica napus L.) in Brandenburg (northeast Germany) were: (i) to quantify the effects of $\mathrm{N}$ fertilization levels on water productivity using a modeling approach and field measurements and (ii) to investigate the underlying causes that explain the differences in water productivity. To achieve these two objectives, the $\mathrm{N}$ fertilization amounts, the measured LAI, modeled transpiration, and modeled evaporation from interception in the vegetation period over a three-year period were used. The purpose was to explore the influence of $\mathrm{N}$ fertilization amounts on 
the hydrological process of evaporation from interception and transpiration to estimate the potential for increasing the productivity of precipitation water use in agriculture.

\section{Materials and Methods}

\subsection{Study Site}

The research presented here is based upon a field experiment within the collaborative project on "Mitigation of greenhouse gas emissions from rapeseed cultivation" [27] and the first study of evaporation from interception in winter oilseed rape [24]. The measurements of those studies were conducted at the Field Experimental Station in Berge in Brandenburg. Table 1 provides the meteorological characteristics of the study site located at $52^{\circ} 37^{\prime} 0^{\prime \prime} \mathrm{N}$ $12^{\circ} 46^{\prime} 60^{\prime \prime}$ E. According to the work of [27], the soil is a luvisol with $5.7 \%$ clay, $19.9 \%$ silt, and $74.4 \%$ sand. In 2012, randomized split-plot experiments with four replicated blocks were established and investigated for four years. Winter oilseed rape was grown on 20 plots with five mineral $\mathrm{N}$ fertilization treatments (in $\mathrm{kg} \mathrm{N} \mathrm{ha}^{-1} \mathrm{a}^{-1}$ ) and four replicates. For each of the four years, the locations of the treatments were changed within the four blocks. The crop rotation with winter oilseed rape (var. "Visby"), winter wheat (Triticum aestivum L., var. "Julius"), and winter barley (Hordeum vulgare L., var. "Tenor") was cultivated as the main plots in each of the four blocks. Winter wheat and winter barley were the crops of the other plots [24].

The size of one plot was $3 \mathrm{~m} \times 13.75 \mathrm{~m}\left(41.25 \mathrm{~m}^{2}\right)$. Sowing of the winter oilseed rape occurred between the end of August and the middle of September. The $\mathrm{N}$ fertilization treatments used were an unfertilized control (N0) and treatments fertilized with 60 (N1), 120 (N2), 180 (N3), and 240 (N4) kg mineral $\mathrm{N} \mathrm{ha}^{-1} \mathrm{a}^{-1}$. In early spring, $90 \mathrm{~kg} \mathrm{~S} \mathrm{ha}^{-1} \mathrm{a}^{-1}$ were applied as kieserite $\left(\mathrm{MgSO}_{4} \cdot \mathrm{H}_{2} \mathrm{O}\right)$ in all winter oilseed rape treatments, including the unfertilized control (N0), to avoid sulfur (S) deficiency. Crop protection and further farming practices were applied according to typical site-specific agricultural practices, and after the harvest, the straw was removed.

\subsection{Measurements}

\subsubsection{Weather}

Hourly and daily values of precipitation (P), temperature (air, soil), humidity, wind (speed, direction), global radiation, and sunshine duration were obtained from the meteorological station of the German Weather Service (DWD), located at a maximum of $250 \mathrm{~m}$ away from the plots. The average annual temperature was $10.1 \pm 0.8^{\circ} \mathrm{C}$ according to this data set measured between January 2012 and December 2015. The temperature in this study period was higher than the long-term mean (Table 1).

\subsubsection{Soil Parameters}

Soil samples were taken with an auger from 0 to $30 \mathrm{~cm}$ soil depth. The soil samples from three insertions per replicate plot were pooled over four replicates, afterward sieved with a mesh size $<5 \mathrm{~mm}$ grader. The texture was determined at 0-30, 30-60, and $60-90 \mathrm{~cm}$ depth according to the world reference base for soil resources of the International Union of Soil Sciences (IUSS) [28]. These soil samplings and analyses were carried out on 28 plots separately. Based on the texture analysis, crop water at field capacity ( $\mathrm{pF}$ 2.0) and at permanent wilting point ( $\mathrm{pF}$ 4.2) in each plot were determined according to the work of [29], assuming a dry bulk density of $1.5 \mathrm{~g} \mathrm{~cm}^{-3}$.

A mean available water capacity of $22 \pm 3 \%$ was determined in the topsoil $0-30 \mathrm{~cm}$ of 28 sampled plots. In 30-60 cm depth, the available water capacity was lower, with $16 \pm 2 \%$. The lowest available water capacity was found in $60-90 \mathrm{~cm}$ depth with $14 \pm 2 \%$. The values measured for each plot in 30-60 cm depth and in 60-90 cm depth were taken into account for the modeling process. 


\subsubsection{Leaf Area Index and Yield}

A SunScan Canopy Analysis System (Delta-T Devices Ltd., Cambridge, UK) was used for measuring LAI. The LAI values were measured plot-wise on 16 days (Table A1). Since weather conditions did not always allow for accurate LAI measurements, the number of included plots varied [24].

Within the specific areas of $1 \mathrm{~m}^{2}$ on each of the plots, the height of the plants was determined. The total fresh matter yield was determined at harvest in July/August by cutting winter oilseed rape plants from $1 \mathrm{~m}^{2}$. The green cut was separated into straw and pods, which were flailed subsequently. Moisture was determined after drying for three days at $60^{\circ} \mathrm{C}$. A standard quality humidity of $9 \%$ for the winter oilseed rape was used for further analysis.

\subsection{Calculations}

\subsubsection{Hydrological Variables}

The modeling software AgroHyd Farmmodel [30] was used daily to calculate both the water flows and the water productivity over the entire vegetation period. Local weather data obtained from the DWD weather station (see Section 2.2.1), crop data, and crop water availability (crop water at field capacity ( $\mathrm{pF}$ 2.0) minus crop water at permanent wilting point ( $\mathrm{pF}$ 4.2)) in each plot were combined for detailed calculation of the local hydrologic processes in each plot, such as evaporation from soil (E), transpiration (T), evaporation of intercepted water (I), and percolation.

The algorithm for calculating the actual crop transpiration $\left(\mathrm{T}_{\text {act }}\right)$ in AgroHyd Farmmodel is based on the FAO 56 dual crop coefficient method from [31]. After calculating the reference evapotranspiration $\left(\mathrm{ET}_{0}\right)$, the potential crop transpiration $\left(\mathrm{T}_{\mathrm{c}}\right)$ and the actual transpiration $\left(\mathrm{T}_{\mathrm{act}}\right)$ are calculated. The reference evapotranspiration of a grass reference surface is calculated using the FAO Penman-Monteith equation with regional climate data [31] in AgroHyd Farmmodel. Subsequently, $\mathrm{T}_{\mathrm{c}}$ is adjusted for the individual crop with plant-specific parameters, e.g., seeding date and harvest date, rooting depth, LAI, and the plant-specific basal crop coefficient $\left(\mathrm{K}_{\mathrm{cb}}\right)$, for each specific development phase (Table 2). A simple tipping bucket approach is used to calculate the daily soil water balance. For this calculation, the daily enlarging root length, a varying available water capacity of the respective soil zone, and precipitation data are combined to determine the water (deficit) stress coefficient (Ks) that reduces $T_{c}$ to $T_{\text {act }}$ [31]. The effect of daily water deficit stress is incorporated by linking the data sets on plant and soil characteristics by the calculation of $\mathrm{T}_{\text {act }}$. In addition, the evaporation and the reference evapotranspiration are calculated following the work of [31]. The rainfall interception calculation in the model is based on the studies by [32,33] taking the measured values of evaporation from interception [24]. A detailed description of the model is given in the work of [12,30].

The crop data were taken from the field measurements and published data from the work of $[31,34]$ (Table 2).

\subsubsection{Water Productivity}

Water productivity was calculated to identify productive water use of plants at the $\mathrm{N}$ fertilization amounts investigated [10,12]. Water input $\left(\mathrm{W}_{\text {input }}\right)$ is the sum of all components of water inflow via air and ground used for crop growth, i.e., transpired water from precipitation, all water inflow via technical means, and indirect water use referring to pre-chains. In this study, indirect water use for the production of fertilizers, machinery, and infrastructure was not considered because it was assumed to be negligible [35]. Since indirect water was excluded and irrigation water was not applied in this study, transpired water stemming from precipitation equals the $W_{\text {input }}$ Transpiration was modeled for the respective vegetation period of the winter oilseed rape, including the preceding fallow period. 
Water productivity can be expressed as Equations (1) and (2):

$$
\mathrm{WP}_{\text {seeds }}=\frac{\text { Mass }_{\text {output }}}{\mathrm{W}_{\text {input }}}
$$

and

$$
\mathrm{WP}_{\text {profit }}=\frac{\text { Monetary }_{\text {output }}}{\mathrm{W}_{\text {input }}}
$$

$\mathrm{WP}_{\text {seeds }}$ denotes the mass-based water productivity $\left(\mathrm{t} \mathrm{m}^{-3}\right)$, and Mass output denotes the mass of harvested crop at standard quality humidity ( $9 \%$ for rapeseed) ( $\mathrm{Mg} \mathrm{ha}^{-1} \mathrm{a}^{-1}$ ). In this study, the mass of the seeds is taken into account as a basis for the calculation of water productivity. $\mathrm{WP}_{\text {profit }}$ denotes economic profit-based water productivity $\left(€ \mathrm{~m}^{-3}\right)$. The profit is calculated as the revenue from harvested crops (crop yield $\times$ crop price $\left(p_{C}\right)$ ) minus the cost of production. Costs of production were estimated according to [22] with $913 € \mathrm{ha}^{-1} \mathrm{a}^{-1}$ costs for cultivation and harvesting winter rapeseed with a default $\mathrm{N}$ fertilizer rate of $145 \mathrm{~kg}$ mineral $\mathrm{N} \mathrm{ha}^{-1} \mathrm{a}^{-1}$. Adjusted fertilizer rates were taken into account with $p_{N}$ of $0.96 € \mathrm{~kg}^{-1} \mathrm{~N}$ for $\mathrm{N}$ fertilizer (calcium ammonium nitrate) [22]. A crop price $\left(p_{C}\right)$ of $340 € \mathrm{t}^{-1}$ was assumed for winter rapeseed.

Table 2. Plant-specific parameters for crop-related modeling (p: evapotranspiration depletion factor, Zr: effective rooting

\begin{tabular}{|c|c|c|c|c|c|c|c|c|c|c|}
\hline \multirow{2}{*}{$\begin{array}{c}\text { Year } \\
\text { Phase }\end{array}$} & \multicolumn{3}{|c|}{ 2012-2013 } & \multicolumn{3}{|c|}{ 2013-2014 } & \multicolumn{3}{|c|}{ 2014-2015 } & \multirow[t]{2}{*}{ Fallow } \\
\hline & Initial & $\begin{array}{l}\text { Mid- } \\
\text { season }\end{array}$ & $\begin{array}{c}\text { Late } \\
\text { season }\end{array}$ & Initial & $\begin{array}{c}\text { Mid- } \\
\text { season }\end{array}$ & $\begin{array}{c}\text { Late } \\
\text { season }\end{array}$ & Initial & $\begin{array}{l}\text { Mid- } \\
\text { season }\end{array}$ & $\begin{array}{c}\text { Late } \\
\text { season }\end{array}$ & \\
\hline Start day $^{a}$ & 1 & 221 & 261 & 1 & 221 & 261 & 1 & 221 & 261 & 1 \\
\hline End day & 220 & 260 & 289 & 220 & 260 & 289 & 220 & 260 & 289 & $42-51$ \\
\hline$p(-)^{b}$ & 0.6 & 0.6 & 0.6 & 0.6 & 0.6 & 0.6 & 0.6 & 0.6 & 0.6 & 0.55 \\
\hline $\mathrm{Zr}(\mathrm{m})^{c}$ & 0.3 & & 1.5 & 0.3 & & 1.5 & 0.3 & & 1.5 & 0.3 \\
\hline Height (m) & & & 1.27 & & & 1.48 & & & 1.49 & 0.3 \\
\hline $\mathrm{K}_{\mathrm{cb}}(-)^{b}$ & 0.15 & 0.95 & 1.1 & 0.15 & 0.95 & 1.1 & 0.15 & 0.95 & 1.1 & 0.15 \\
\hline$L A I\left(\mathrm{~m}^{2} \mathrm{~m}^{-2}\right)$ & 0.2 & & $2.9-6.8$ & 0.2 & & $1.6-6.7$ & 0.2 & & $2.1-10.3$ & 0.2 \\
\hline Periods & 10 Sep & $\begin{array}{c}\text { mber } 2012 \\
2013\end{array}$ & August & 5 Septe & $\begin{array}{r}\text { ember } 20 \\
2014\end{array}$ & -16 July & 3 Sep & $\begin{array}{r}\text { mber } 20 \\
2015\end{array}$ & -28 July & $\begin{array}{c}31 \text { July-10 } \\
\text { September } 2012 \\
16 \text { July-5 } \\
\text { September } 2013 \\
15 \text { July-3 } \\
\text { September } 2014\end{array}$ \\
\hline
\end{tabular}
depth, $\mathrm{K}_{\mathrm{cb}}$ : basal crop coefficient, LAI: leaf area index).

${ }^{a}$ day of the growing period; ${ }^{b}[31] ;^{c}[34]$.

\subsubsection{Calculation of Optimum Nitrogen Fertilization Rates}

The calculation of the profit-maximizing level of optimal $\mathrm{N}$ fertilizer rates or maximum economic return to $\mathrm{N}$ fertilizer (MERN) was based on quadratic crop yield response functions, estimated with the crop yield response to the fertilizer treatments in the experiment (Equation (3)),

$$
Y(\mathrm{~N})=a \times \mathrm{N}^{2}+b \times \mathrm{N}+c
$$

where $a, b, c$ are coefficients of the regression calculation between yield $(Y)\left(\mathrm{Mg} \mathrm{ha}^{-1} \mathrm{a}^{-1}\right)$ and nitrogen $(\mathrm{N})$ level ( $\mathrm{kg}$ mineral $\mathrm{N} \mathrm{ha}^{-1} \mathrm{a}^{-1}$ ) (Equation (3)), which are as well input to 
Equation (4). MERN was identified as the point where the marginal profit $p_{C}$ from $\mathrm{N}$ fertilizer increase equals the cost of $\mathrm{N}$ fertilizer $p_{N}$ (Equation (4)).

$$
\operatorname{MERN}\left(p_{C}, p_{N}\right)=\frac{\left(\frac{p_{N}}{p_{C}}-b\right)}{a}
$$

Furthermore, maximal $\mathrm{WP}_{\text {profit }}$ was calculated based on the crop yield response function, costs for $\mathrm{N}$, and water input (Equation (2)) and indicated as optimum $\mathrm{N}$ fertilizer levels with respect to monetary-based water productivity $\mathrm{WP}_{\text {profit. }}$. There are no costs for the water input in this study since it is a rainfed winter oilseed rape cultivation.

\subsubsection{Statistical Analyses}

A linear ANOVA model was used to test the influence of the five fertilization treatments in the three years on each of the five traits: yield, LAI, evaporation of interception, transpiration, and $\mathrm{WP}_{\text {seed }}$. Due to larger differences in variance between the years, heteroscedastic models were fitted. For each trait, it was checked if there was a significant interaction between fertilizer treatment and year. No significant interactions were found; thus, all models only included the two main factors, fertilizer treatment and year.

Significant factors were tested for differences between their factor levels using multiple pairwise comparisons. A simulation method was used to adjust $p$-values for multiple testing to keep the global significance level of 0.05 .

All statistical analyses were conducted using SAS 9.4 (SAS Institute Inc., Cary, NC, USA).

\subsubsection{Calculation of Uncertainty}

The following sources of uncertainty in the water fluxes, yield data, and water productivity calculations were considered: (1) natural randomness, (2) input data, and (3) model parameters and structure. The uncertainties were evaluated based on the experimental approach.

(1) Natural randomness $\left(X_{N}\right)$

The coefficient of variation $(\mathrm{CV})$ resulting from the ratio of the standard deviation to the mean of precipitation considering the three vegetation periods (Table 1) was used as a measure of natural randomness of the measured precipitation $\left(\mathrm{X}_{\mathrm{N}, \mathrm{P}}\right)$ with precipitation $(\mathrm{P})$.

(2) Input data $\left(\mathrm{X}_{\mathrm{I}}\right)$

The error of Hellmann-type gauges $\left(\mathrm{X}_{\mathrm{I}, \mathrm{P}}\right)$ ranges from $2 \%$ to $12.5 \%$ for rainfall intensities between 25 and $0.01 \mathrm{~mm}$ but also depends on wind speed. At a wind speed of $5 \mathrm{~m} \mathrm{~s}^{-1}$, the error is less than 5\% [36]. This value of 5\% was included in the calculation of error of Hellmann-type gauges. The uncertainty resulting from the spatial distribution of precipitation was considered negligible. The incident precipitation hourly measured and logged at the meteorological station in Berge is affected by the same error as the Hellmann-type gauges.

The uncertainty of yield measurements (Mass output $_{\text {) }}$ and the uncertainty of modeled transpiration ( $\mathrm{W}_{\text {input }}$ ) as explained below were considered to quantify the overall uncertainty of the WP values. Then, the alternative WP was calculated using minimum and maximum values of Mass output $_{\text {and }} \mathrm{W}_{\text {input }}$. The coefficients of variation resulting from the ratio of the standard deviation to the mean seed yield were used for the uncertainty assessment of the Mass output $_{\text {measurements }}\left(\mathrm{X}_{\mathrm{I}, \mathrm{M}}\right)$.

(3) Model parameters and model structure $\left(X_{M}\right)$

The uncertainties associated with the modeling process of transpiration $\left(\mathrm{X}_{\mathrm{M}, \mathrm{T}}\right)$ and evaporation of interception $\left(\mathrm{X}_{\mathrm{M}, \mathrm{I}}\right)$ were calculated for the uncertainty assessment of the $\mathrm{W}_{\text {input }}$. AgroHyd Farmmodel consists of different components and algorithms associated with different sources of uncertainty. The uncertainty analysis used here focuses on transpiration modeling and interception modeling. An assumed maximum standard deviation 
of the differences (SD) was used to calculate the uncertainty of modeled transpiration resulting from model parameters and model structure. The assumed high value originates from another model application in which the transpiration values were compared with measured values and had to be considered as a maximum value [37]. The SD between the modeled and the measured values from [24] were calculated for the assessment of the uncertainty in the interception modeling.

\section{Results}

\subsection{Influence of $N$ Fertilization Levels}

3.1.1. Influence of N Fertilization Levels on Leaf Area Index and Seed Yield

The mean LAI values of each fertilization treatment varied between 2.5 and 6.5 (Figure 1a). Mean seed yield of each fertilization level was between 2.85 and $4.85 \mathrm{Mg} \mathrm{ha}^{-1} \mathrm{a}^{-1}$ (Figure 1b). Seed yield and LAI increased with higher fertilization treatments. However, for $\mathrm{N}$ fertilization, the analyses of the differences of the mean showed that on amounts higher than $120 \mathrm{~kg} \mathrm{~N} \mathrm{ha}^{-1} \mathrm{a}^{-1}$, the LAI and yield increases were not significant from those at a fertilization treatment of $120 \mathrm{~kg} \mathrm{~N} \mathrm{ha}^{-1} \mathrm{a}^{-1}$ (Table 3).

\subsubsection{Influence of $\mathrm{N}$ Fertilization Levels on Hydrological Variables}

The modeled mean evaporation from interception of all $\mathrm{N}$ fertilization treatments was $179 \pm 25 \mathrm{~mm}(33 \% \pm 6 \%$ of $\mathrm{P})$ and varied from 152 to $194 \mathrm{~mm}(28 \%$ to $36 \%$ of $\mathrm{P})$ (Figure 1c). The mean transpiration values of each fertilization stage varied between 238 and $258 \mathrm{~mm}$ (Figure 1d). $\mathrm{WP}_{\text {seeds }}$ values of each fertilization stage varied from $1.12 \mathrm{~kg} \mathrm{~m}^{-3}$ to $2.03 \mathrm{~kg} \mathrm{~m}^{-3}$ (Figure 1e).

Evaporation from interception and $\mathrm{WP}_{\text {seeds }}$ increased with higher fertilization amounts.

As for the yield and LAI, $\mathrm{N}$ fertilization amounts higher than $120 \mathrm{~kg} \mathrm{~N} \mathrm{ha}^{-1} \mathrm{a}^{-1}$ did not result in significant increases in evaporation from interception, transpiration, and $\mathrm{WP}_{\text {seeds }}$ (Table 3) $(n=60)$.

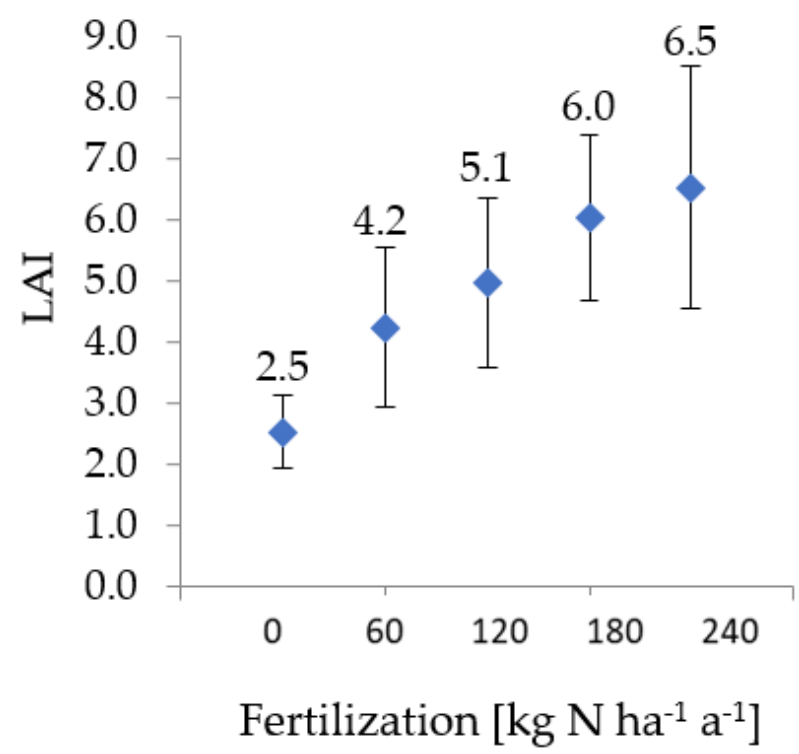

(a)

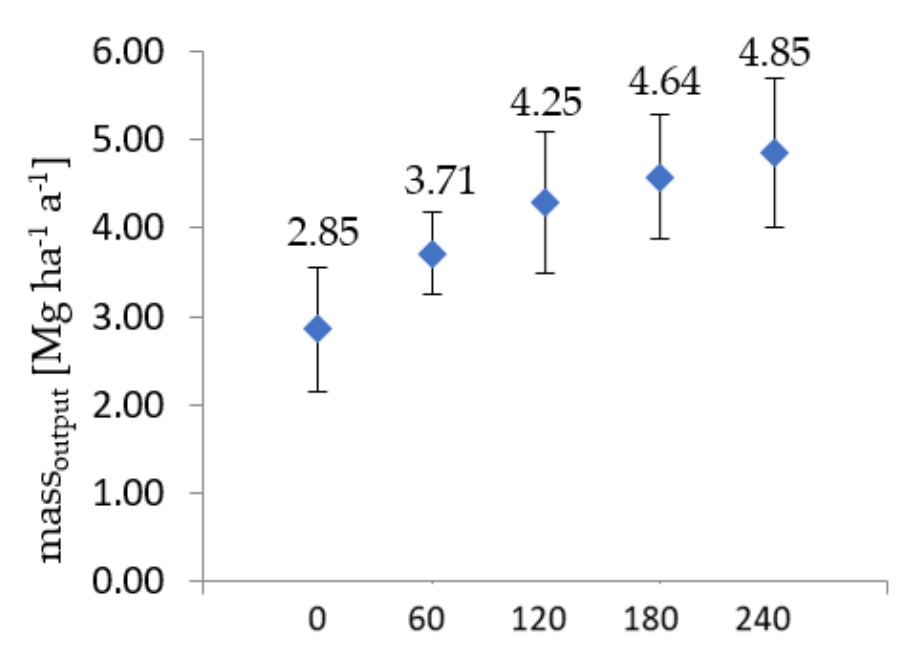

Fertilization $\left[\mathrm{kg} \mathrm{N} \mathrm{ha-1} \mathrm{a}^{-1}\right]$

(b)

Figure 1. Cont. 


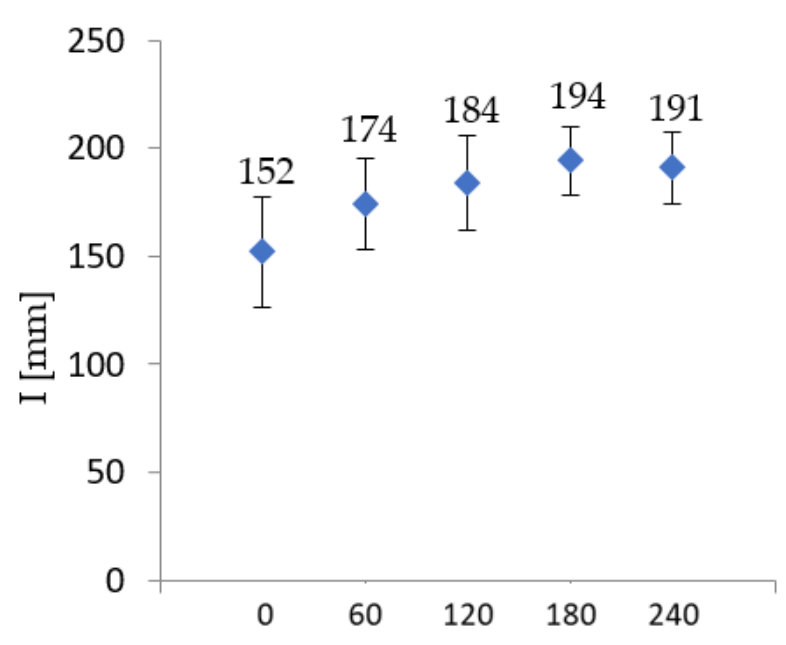

Fertilization $\left[\mathrm{kg} \mathrm{N} \mathrm{ha-1} \mathrm{a}^{-1}\right]$

(c)

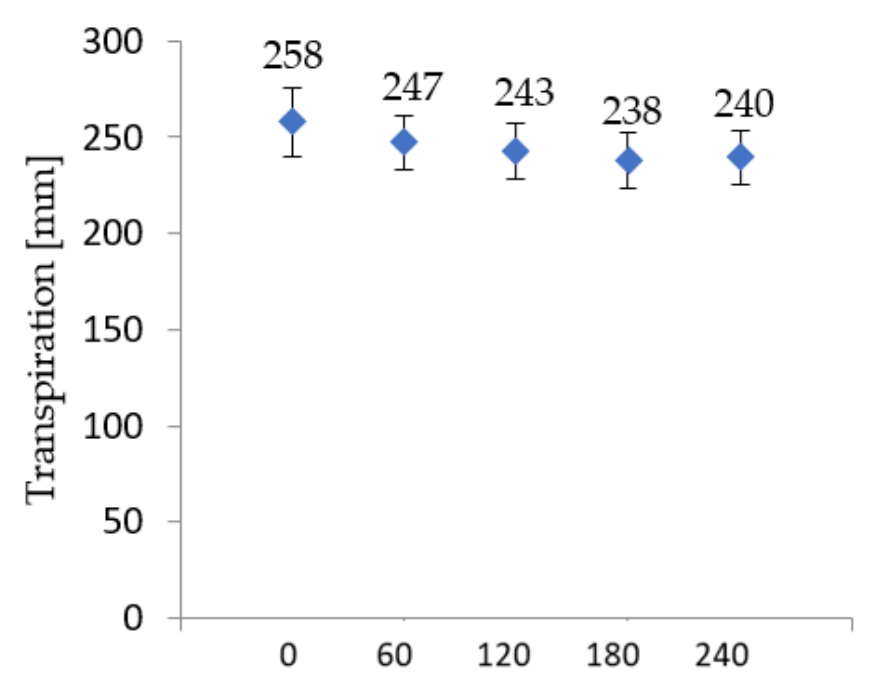

Fertilization $\left[\mathrm{kg} \mathrm{N} \mathrm{ha}^{-1} \mathrm{a}^{-1}\right]$

(d)

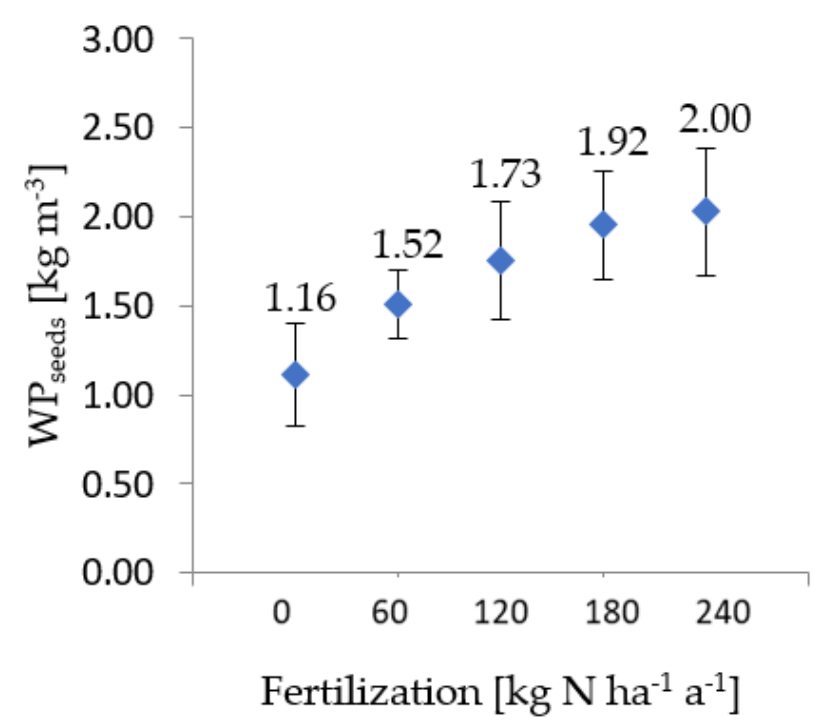

(e)

Figure 1. (a) Mean LAI values, (b) mean seed yield, (c) mean modeled evaporation from interception values (mm), (d) mean modeled transpiration $(\mathrm{mm}),(\mathbf{e})$ mean water productivity of the seeds $\left(\mathrm{WP}_{\text {seeds }}\right)$ each with standard deviations of the five fertilization treatments 0 (N0), 60 (N1), 120 (N2), $180(\mathrm{~N} 3)$, and 240 (N4) $\mathrm{kg}$ mineral $\mathrm{N} \mathrm{ha}^{-1} \mathrm{a}^{-1}$ based on the raw data $(n=60)$ for the three vegetation periods 2014, 2015, and 2016.

\subsection{Variance of the Three Years and of the N Fertilization Levels}

The variance analysis of each of the three years showed significant differences for all five traits, i.e., WP, yield, LAI, evaporation of interception, and transpiration. Significant differences also showed up in the different fertilization treatments (Table 3). 
Table 3. Least square means with lower and upper 95\% confidence limits of yield, LAI, evaporation from interception (I) transpiration (T), and water productivity (WP) of the five fertilization treatments 0 (N0), 60 (N1), 120 (N2), 180 (N3), and 240 (N4) $\mathrm{kg}_{\text {mineral }} \mathrm{N} \mathrm{ha}^{-1} \mathrm{a}^{-1}$. Different upper letters within a trait indicate significant differences between the $\mathrm{N}$ fertilizer treatments within one year as well as between years (multiple pairwise tests with simulation adjustment, $\alpha=0.05$ ).

\begin{tabular}{|c|c|c|c|c|c|c|}
\hline Factors & Factor Levels & $\underset{\left(\mathrm{Mg} \mathrm{ha}^{-1} \mathrm{a}^{-1}\right)}{\text { mass }_{\text {output }}}$ & $\begin{array}{l}\text { LAI } \\
(-)\end{array}$ & $\begin{array}{c}\mathrm{I} \\
(\mathrm{mm})\end{array}$ & $\begin{array}{c}\mathrm{T} \\
(\mathrm{mm})\end{array}$ & $\begin{array}{l}\text { WP } \\
\left(\mathrm{kg} \mathrm{m}_{\text {seeds }}^{-3}\right)\end{array}$ \\
\hline \multirow{6}{*}{ Year } & \multirow{2}{*}{2013} & $3.75^{\mathrm{A}}$ & $4.83^{\mathrm{B}}$ & $180.5^{\mathrm{B}}$ & $243.2^{\mathrm{A}}$ & $1.55^{\mathrm{A}}$ \\
\hline & & {$[3.55 ; 3.94]$} & {$[4.23 ; 5.42]$} & {$[174.2 ; 186.8]$} & {$[238.6 ; 247.7]$} & {$[1.47 ; 1.64]$} \\
\hline & \multirow{2}{*}{2014} & $4.81^{\mathrm{B}}$ & $3.84^{\mathrm{A}}$ & $159.4^{\mathrm{A}}$ & $250.4^{\mathrm{B}}$ & $1.94^{\mathrm{B}}$ \\
\hline & & {$[4.56 ; 5.06]$} & {$[3.36 ; 4.31]$} & {$[151.4 ; 167.3]$} & {$[246.9 ; 254.0]$} & {$[1.82 ; 2.06]$} \\
\hline & \multirow{2}{*}{2015} & $3.61^{\mathrm{A}}$ & $5.89^{C}$ & $191.7^{C}$ & $243.4^{\mathrm{AB}}$ & $1.52^{\mathrm{A}}$ \\
\hline & & {$[3.42 ; 3.79]$} & {$[5.35 ; 6.44]$} & {$[187.1 ; 196.2]$} & {$[232.9 ; 253.9]$} & {$[1.39 ; 1.64]$} \\
\hline \multirow{10}{*}{$\begin{array}{c}\text { Fertilization } \\
\text { treatment } \\
\left(\mathrm{kg} \mathrm{mineral}^{-1} \mathrm{~N} \mathrm{ha}^{-1} \mathrm{a}^{-1}\right)\end{array}$} & \multirow{2}{*}{0} & $2.85^{\mathrm{A}}$ & $2.62^{\mathrm{A}}$ & $134.9^{\mathrm{A}}$ & $260.5^{B}$ & $1.16^{\mathrm{A}}$ \\
\hline & & {$[2.59 ; 3.12]$} & {$[1.78 ; 3.47]$} & {$[125.6 ; 144.3]$} & {$[252.3 ; 268.7]$} & {$[1.02 ; 1.30]$} \\
\hline & \multirow{2}{*}{60} & $3.75^{\mathrm{B}}$ & $4.22 \mathrm{AB}$ & $175.0^{\mathrm{B}}$ & $249.7 \mathrm{AB}$ & $1.52^{\mathrm{B}}$ \\
\hline & & {$[0.35 ; 0.40]$} & {$[3.38 ; 5.07]$} & {$[165.6 ; 184.3]$} & {$[241.5 ; 257.9]$} & {$[1.39 ; 1.66]$} \\
\hline & \multirow{2}{*}{120} & $0.43^{B C}$ & $5.01 \mathrm{BC}$ & $184.5^{\mathrm{BC}}$ & $243.7^{\mathrm{A}}$ & $1.73^{\mathrm{BC}}$ \\
\hline & & {$[3.49 ; 4.02]$} & {$[4.47 ; 5.56]$} & {$[178.5 ; 190.6]$} & {$[238.8 ; 248.6]$} & {$[1.59 ; 1.88]$} \\
\hline & \multirow{2}{*}{180} & $4.60^{C}$ & $5.96^{\mathrm{C}}$ & $193.9^{C}$ & $238.3^{\mathrm{A}}$ & $1.92^{C}$ \\
\hline & & {$[4.35 ; 4.86]$} & {$[5.45 ; 6.46]$} & {$[188.4 ; 199.4]$} & {$[233.5 ; 243.2]$} & {$[1.79 ; 2.06]$} \\
\hline & \multirow{2}{*}{240} & $4.81^{C}$ & $6.42^{C}$ & $197.6^{C}$ & $236.2^{\mathrm{A}}$ & $2.00^{C}$ \\
\hline & & {$[4.54 ; 5.08]$} & {$[5.59 ; 7.29]$} & {$[188.2 ; 206.9]$} & {$[228.0 ; 244.4]$} & {$[1.87 ; 2.14]$} \\
\hline
\end{tabular}

\subsection{Optimum Nitrogen Fertilization Rates}

The yield increased with an increasing nitrogen fertilization rate (Figure 2). The maximum economic return to $\mathrm{N}$ fertilizer (MERN) based on the average yield response to $\mathrm{N}$ was found at $215 \mathrm{~kg}$ mineral $\mathrm{N} \mathrm{ha}^{-1} \mathrm{a}^{-1}$ (between 176 and $316 \mathrm{~kg}$ mineral $\mathrm{N} \mathrm{ha}^{-1} \mathrm{a}^{-1}$ for the respective years).

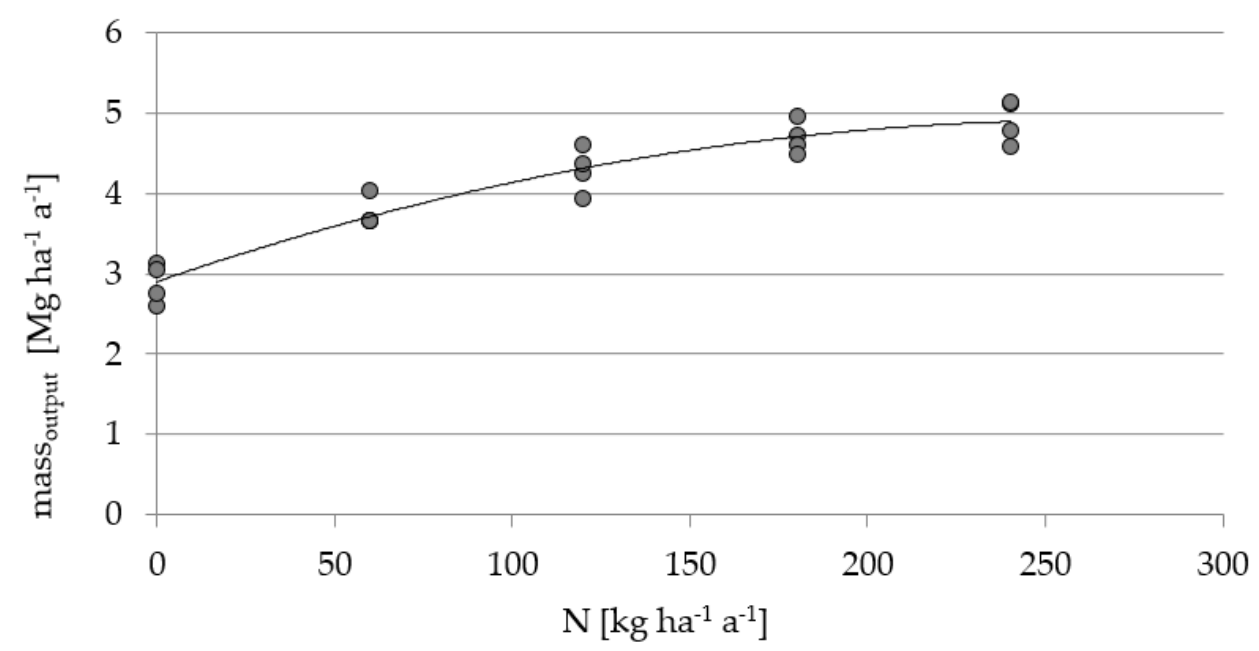

Figure 2. Relationship between crop yield (yield) and fertilizer treatments $(\mathrm{N})$ with quadratic crop yield response function in the experiment (Equation (3)) for the three years.

The monetary-based water productivity increased with increasing nitrogen fertilization levels (Figure 3). The optimum $\mathrm{N}$ level for the maximal $\mathrm{WP}_{\text {profit }}$ of the three years was at $200 \mathrm{~kg}$ mineral $\mathrm{N} \mathrm{ha}^{-1} \mathrm{a}^{-1}$ (between 175 and $290 \mathrm{~kg}$ mineral $\mathrm{N} \mathrm{ha}^{-1} \mathrm{a}^{-1}$ for the respective years) and thus nearly the same as the optimum nitrogen fertilization rates for the yield. 


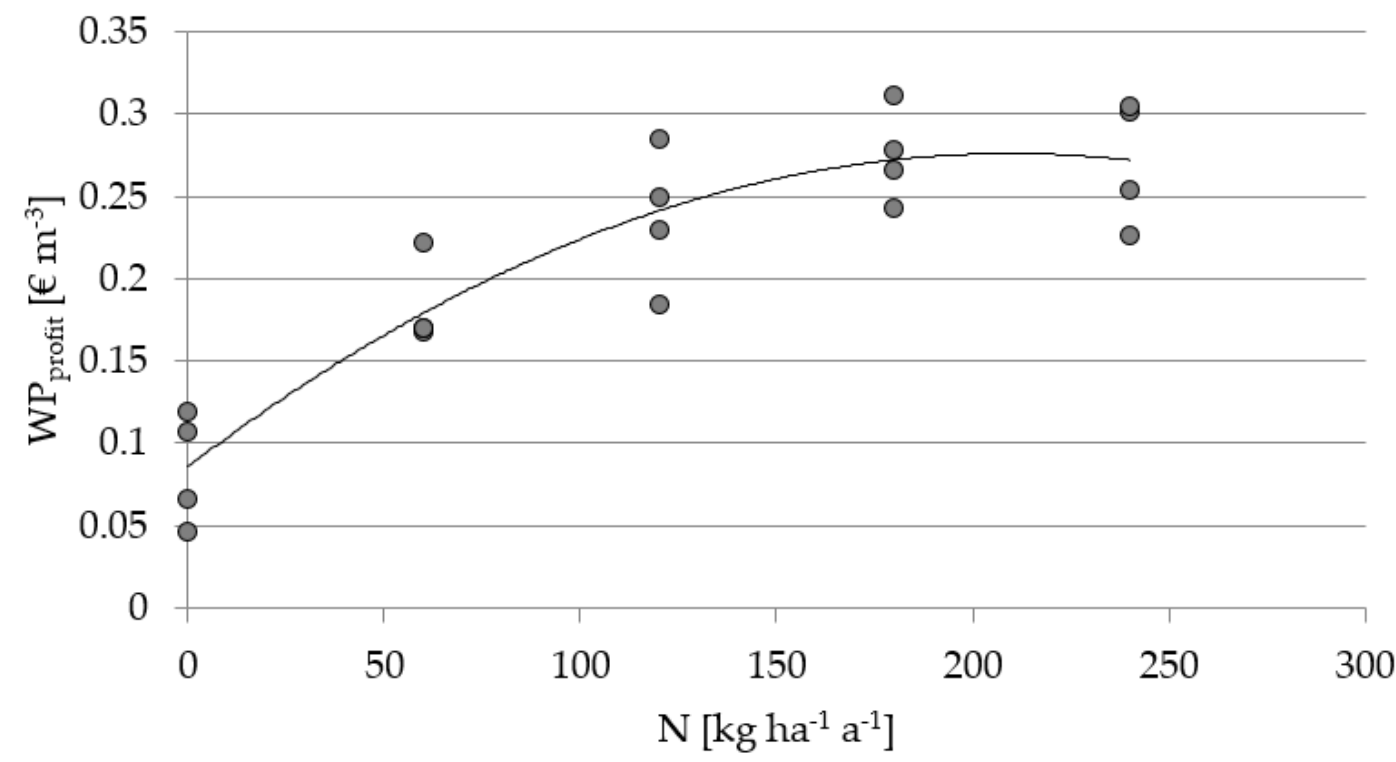

Figure 3. Relationship between monetary-based water productivity $\left(\mathrm{WP}_{\text {profit }}\right)$ and fertilizer treatments $(\mathrm{N})$ with quadratic crop yield response function estimated in the experiment (Equation 4) for the three years.

\subsection{Uncertainty}

The assumed error in the measured precipitation $(\mathrm{P})$ was low due to the excellent reliability of Hellmann-type rain gauges used by the German weather service located at a short distance of $250 \mathrm{~m}$ from the plots. Nevertheless, the measurement of P might be associated with an error due to wind field deformation above the gauge inlet (Table A2). Errors regarding the seed yield were high, as shown through the high coefficient of variation from $13 \%$ to $24 \%$ (Table A2). The uncertainties associated with the modeling process of the water fluxes were high, resulting from the uncertainty of model parameters and model structure. This is reflected in the high uncertainties in transpiration $\left(\mathrm{X}_{\mathrm{I}, \mathrm{T}}\right)$. Estimates of water productivity that were determined have a large margin of error since all errors of input measurements accumulate (Table 4).

Table 4. Minimum and maximum estimates of mean fluxes, mass output, and water productivity for the five fertilization treatments N0-N4 ( $\left.\mathrm{kg} \mathrm{N} \mathrm{ha}^{-1} \mathrm{a}^{-1}\right)$ in the years 2013-2015, including all errors from the experimental results. I, evaporation from interception; $\mathrm{T}$, transpiration; $\mathrm{Mass}_{\text {output }}$, seed yield; $\mathrm{P}$, precipitation; $\mathrm{W}_{\text {input }}$, water input; $\mathrm{WP}_{\text {seeds }}, \mathrm{water}$ productivity seeds.

\begin{tabular}{ccccccccccc}
\hline Treatment & \multicolumn{2}{c}{ N0 (0) } & \multicolumn{2}{c}{ N1 (60) } & \multicolumn{2}{c}{ N2 (120) } & \multicolumn{2}{c}{ N3 (180) } & N4 (240) \\
\hline & Min & Max & Min & Max & Min & Max & Min & Max & Min & Max \\
\hline P (mm) & 496 & 580 & 496 & 580 & 496 & 580 & 496 & 580 & 496 & 580 \\
I (mm) & 0 & 318 & 0 & 364 & 0 & 384 & 0 & 406 & 0 & 399 \\
I (\% of PMax) & 0 & $55 \%$ & 0 & $63 \%$ & 0 & $66 \%$ & 0 & $70 \%$ & 0 & $69 \%$ \\
T (mm) & 142 & 374 & 136 & 359 & 134 & 352 & 131 & 345 & 132 & 347 \\
Mass $_{\text {output }}\left(\mathrm{kg} \mathrm{m}\right.$ m $\left.^{-2}\right)$ & 0.29 & 0.36 & 0.37 & 0.42 & 0.42 & 0.50 & 0.46 & 0.53 & 0.48 & 0.57 \\
WP $_{\text {seeds }}$ & 0.76 & 2.50 & 1.04 & 3.07 & 1.21 & 3.75 & 1.34 & 4.08 & 1.40 & 4.33 \\
\hline
\end{tabular}

\section{Discussion}

\subsection{Influence of N Fertilization Levels on LAI, Yield, Hydrological Variables, and WP}

The highest water productivity was detected for the highest $\mathrm{N}$ fertilization rate. There was no significant difference, however, between the water productivity of the fertilization rates 120,180 , and $240 \mathrm{~kg}$ mineral $\mathrm{N} \mathrm{ha}^{-1} \mathrm{a}^{-1}$. Resulting from the findings of this study, fertilization of $120 \mathrm{~kg}$ mineral $\mathrm{N} \mathrm{ha}^{-1} \mathrm{a}^{-1}$ is sufficient to reach $\mathrm{WP}_{\text {seeds }}$ not significantly lower than from higher fertilization rates. This rate of $120 \mathrm{~kg}$ mineral $\mathrm{N} \mathrm{ha}^{-1} \mathrm{a}^{-1}$ found 
in this study is lower than the site-specific $\mathrm{N}$ fertilization amount of $150-170 \mathrm{~kg}$ mineral $\mathrm{N} \mathrm{ha}^{-1} \mathrm{a}^{-1}$ [22], depending as well strongly on yield expectations and nitrogen reserves in the soil. The results of [38] showed the highest $\mathrm{WP}_{\text {seeds }}$ occurring when the rapeseed crops received a regular supply of $\mathrm{N}$ throughout the season, i.e., $200 \mathrm{~kg} \mathrm{~N} \mathrm{ha}^{-1}$ in five splits. The study was conducted on calcisols in South Australia. This value is lower than the findings in this study, the highest $\mathrm{WP}_{\text {seeds }}$ of $2.00 \mathrm{~kg} \mathrm{~m}^{-3}$ was discovered for the highest fertilization stage of $240 \mathrm{~kg} \mathrm{~N} \mathrm{ha}^{-1}$.

In the study presented here, winter oilseed rape yields increased with higher amounts of $\mathrm{N}$ fertilization. The mean seed yields followed the pattern of mean German winter rapeseed yields, which were 3.96, 4.48, and $3.91 \mathrm{Mg} \mathrm{ha}^{-1} \mathrm{a}^{-1}$ in 2013, 2014, and 2015, respectively [39]. LAI increased with higher amounts of $\mathrm{N}$ fertilization. Our results for the maximum LAIs ranging from 2.53 to 6.51 are in the upper end of or above the results in the literature of 0.04-3.91 [40] and 0-3.5 [41]. A maximum value of 3.7 was reported from [42].

$\mathrm{WP}_{\text {seeds }}$ values found in this study for the unfertilized control sample (N0) are within the range of $0.4-1.8 \mathrm{~kg} \mathrm{~m}^{-3}$ reported from 42 different case studies simulated by [43] for southern New South Wales (Australia). $\mathrm{WP}_{\text {seeds }}$ increased with increasing $\mathrm{N}$ fertilization amounts, which is in line with the findings of [38]. Furthermore, $\mathrm{WP}_{\text {seeds }}$ increased with an increased yield of seeds, LAI, and modeled evaporation from interception. $\mathrm{WP}_{\text {seeds }}$ showed a slight tendency to decrease with increased modeled transpiration. A tendency of a decreased transpiration with increasing yield was found in the presented study. More water seems to be intercepted and evaporated from the plant surfaces. With higher $\mathrm{N}$ fertilization amounts, transpiration decreases considerably less than interception increases in this study. Increasing fertilization treatments resulted in gradual and clear increase from $45 \%$ to $67 \%$ interception of precipitation [24]. Hence, less soil water was available with increasing amounts of fertilization since the water fraction evaporating from the canopy increases. The yields in the study of [43] showed a different effect: Yield increased with increasing transpiration and a high proportion of $82 \%$ of the variance in seed yield could be explained with the water supply predictor for modeled values of 42 different data sets. The main factors determining evaporation from interception appeared to be LAI, plant architecture, and meteorological conditions during the crop cycle [24].

The higher evaporation from interception, a non-productive water flow, showed no negative effect on WP in this study. The modeled mean $W P_{\text {seeds }}$ was $1.67 \pm 0.44 \mathrm{~kg} \mathrm{~m}^{-3}$ averaged across all treatments. This is higher than the values of 0.57 and $0.58 \mathrm{~kg} \mathrm{~m}^{-3}$ reported from [38] for two years in South Australia.

\subsection{Optimum Nitrogen Fertilization Rates}

Based on the average crop yield response to $\mathrm{N}$ fertilizer, economically optimal $\mathrm{N}$ rates were nearly equal to the water productivity-maximizing $\mathrm{N}$ rates and higher than the economic optima found by [23] in Schleswig-Holstein, Germany. The calculated optima were higher than the recommended $\mathrm{N}$ rates [44] and do not comply with the current regulation of $\mathrm{N}$ use in crop farming. However, since the yield functions are rather flat at the optimum, the cost of considering this restriction can be expected to be rather low.

\subsection{Uncertainty and Method Applied}

The bandwidth of estimates of mean fluxes, mass output, and water productivity for the five fertilization treatments demonstrate that field measurements and modeling approaches need to be planned, conducted, and applied meticulously and with high expertise to adequately consider the various sources of uncertainty. The reason for the uncertainty of the modeling of transpiration is that the same plant parameters, i.e., evapotranspiration depletion factor $(\mathrm{p})$, effective rooting depth $(\mathrm{Zr})$, and basal crop coefficient $\left(\mathrm{K}_{\mathrm{cb}}\right)$, are used for each fertilization level. A calibration with transpiration measured over at least one vegetation period or the use of improved specific plant parameters $\left(\mathrm{K}_{\mathrm{cb}}\right)$, or calibration using both of these could reduce the uncertainty of the modeled values considerably. 
It was demonstrated here that the inclusion of the fraction of precipitation that contributes to plant biomass generation and the exclusion of evaporated water is more meaningful for the analysis of the effect of $\mathrm{N}$ fertilization amounts on WP. The inclusion of evaporation would have superimposed the small effect of the decreasing transpiration found here. The method used in this study [12] includes solely transpiration water as input into the input/output relationship of the WP. The rationale for this approach is that the total precipitation results from a natural process beyond the farmers' control. They can only influence control to a certain degree the fraction of precipitation that infiltrates into the soil and how much of this fraction is transpired by plants. The method from [12] excludes soil evaporation from the water input, as it is not involved in biomass generation and should be minimized. After all, a harmonization of water productivity and efficiency indicators for agricultural production systems has not yet been pursued, despite broad acceptance in the scientific community. Numerous challenges exist to achieve a consistent and coordinated application of water productivity analysis to, e.g., complex multi-step production-consumption chains. Although the denominator is always the unit of water consumed, various studies use different kinds of water use to estimate WP values, including "biomass:transpiration"; "biomass:evapotranspiration"; or "biomass:water inflows", which makes it difficult to compare water productivity in different agricultural production systems [45]. Similarly, the variation in the type of output product (e.g., dry matter, fresh matter, protein value, calorific value, monetary value, etc.) creates an array of WP values. Hence, there is a need to standardize the definition and framework for determining WP in the agricultural sector.

The key factors to be considered in WP accounting can be summarized as:

- the types of water used (i.e., technical water, evapotranspiration water originating from precipitation and waste water);

- the inclusion of transpiration vs. evapotranspiration as water input;

- the inclusion of different outputs;

- the focus on direct water use in agricultural production vs. water demand for production inputs often referred to as indirect water use, e.g., building materials, machinery, energy, fertilizer; and

- the different goals and scales of the studies.

The application scale of the framework from [12] applied in this study was mainly the farm or the field scale. The general goal of the framework was the development of a methodology for estimating water flows at the farm scale in order to derive and apply indicators for optimizing water use by adapting agronomic practices and farm management.

\subsection{Other Agronomic Practices}

For rapeseed, the following practices to substantially increase the productivity of precipitation water use were found:

Soil tillage: The work of [46] investigated the influence of land forming and tillage effects on soil properties and productivity of rapeseed. Broad bed and furrow and raised bed land configurations along with residue and hedge leaves mulching under no-till improved soil quality and was the most suitable for higher returns of groundnut-rapeseed system under rainfed condition. Crop rotation: The work of [47] investigated mixotrophic cultivations and found higher instantaneous water use efficiency in photoautotrophic conditions compared to photomixotrophic rapeseed plants. Breeding: The work of [48] investigated two contrasting rapeseed genotypes, Qinyou 8, drought-sensitive, and Q2, drought-tolerant. The findings of the authors provided evidence for the physiological role of melatonin in improving drought resistance). Coverage: Film mulching was found to have a remarkable effect on microbial diversity positively correlated with soil water content, which is beneficial to increase production [49]. The work of [50] recommended biodegradable film as a viable option to the conventional PE film for the production of winter oilseed rape. Fertilizing with integrated technologies: straw mulching and 
reduced slow-release fertilizer and ridge-furrow rainfall harvesting system and reduced slow-release fertilizer significantly increased rapeseed yield and WUE and fertilizer use efficiency compared with conventional planting patterns [51].

\section{Conclusions}

This study, which covers three years of rainfed winter oilseed rape cultivated under five $\mathrm{N}$ fertilization rates in one of the driest regions in Germany and Europe, shows that there is a clear and positive effect from fertilization on precipitation water productivity.

The evaporation from interception and transpiration behave inversely proportionately depending on the $\mathrm{N}$ fertilization amounts. With increasing $\mathrm{N}$ fertilization, the evaporation from interception increases (because the LAI increases), and the transpiration decreases. The knowledge about the influence of farm management practice fertilization on the hydrological process of evaporation from interception and transpiration can best be assessed by using a method including solely transpiration water as input into the "input/output" relationship of the WP. The inclusion of evaporation would superimpose the small effect of transpiration water found here.

The interaction between fertilization with other farm management practices such as soil tillage, crop rotation, breeding, and coverage practices as well as the relationship between the profit-maximizing level of $\mathrm{N}$ fertilization and the monetary water productivity need to be taken into account in successive studies.

The method water productivity and the assessment of uncertainties associated with the calculations as recommended in the recently developed guidelines of the FAO on water use in agriculture (FAO, 2019; Boulay et al. 2021) are useful for estimating water flows at farm scale in order to derive and apply indicators for optimizing water use by adapting agronomic practices and farm management. The inclusion of the fraction of precipitation that contributes to plant biomass generation and the exclusion of evaporated water is more meaningful for the analysis of the effect of $\mathrm{N}$ fertilization amounts on water productivity.

Author Contributions: Conceptualization, K.D. and A.P.; methodology, K.D.; software, K.D. and C.A.; data curation, K.D. and A.M.-A.; writing-original draft preparation, K.D., A.P., C.A., A.M.-A. and U.K.; writing-review and editing, K.D., A.P., C.A., A.M.-A. and U.K.; visualization, K.D., C.A. and A.M.-A.; supervision, K.D. and A.P. All authors have read and agreed to the published version of the manuscript.

Funding: The data used in this study was part of research funded by the German Federal Ministry of Food and Agriculture and managed by the Agency for Renewable Resources under grant 22403912.

Institutional Review Board Statement: Not applicable.

Informed Consent Statement: Not applicable.

Data Availability Statement: Parts of the data presented in this study are available on request from the corresponding author. Restrictions may apply to the availability of data stemming from the other partners of the collaborative project on "Mitigation of greenhouse gas emissions from rapeseed cultivation" funded by the German Federal Ministry of Food and Agriculture.

Acknowledgments: This study would not have been possible without the diligent work of Judy Libra, Helen Jacobs, Sarah Zügel, Jutta Venzke, Ronny Becher, Anne-Katrin Thoma, Angelika Krüger, Astrid Zimmermann, Christina Hadler, Mirjam Zörner, Maximilian Balk, Lars Eulenburg, Christian Ohlhoff, Jan Drastig, and Benjamin Trost, to whom we are very grateful.

Conflicts of Interest: The authors declare no conflict of interest. 


\section{Appendix A}

Table A1. Dates and number of plots for LAI measurements in the three years 2013, 2014, and 2015.

\begin{tabular}{|c|c|c|c|c|c|c|c|}
\hline Date & 15 May 2013 & 29 May 2013 & 12 June 2013 & 3 July 2013 & 17 July 2013 & & \\
\hline Number of plots & 16 & 16 & 16 & 16 & 16 & & \\
\hline Date & 12 April 2014 & 23 April 2014 & 21 May 2014 & 18 June 2014 & 27 June 2014 & 2 July 2014 & 16 July 2014 \\
\hline Number of plots & 6 & 6 & 20 & 20 & 6 & 20 & 6 \\
\hline Date & 22 April 2015 & 6 May 2015 & 27 May 2015 & 10 June 2015 & & & \\
\hline Number of plots & 20 & 19 & 18 & 20 & & & \\
\hline
\end{tabular}

Table A2. Errors (\%) stemming from natural randomness $\left(\mathrm{X}_{\mathrm{N}}\right)$, input data $\left(\mathrm{X}_{\mathrm{I}}\right)$, and model parameters and model structure $\left(X_{M}\right)$ for the five fertilization treatments $\mathrm{N} 1-\mathrm{N} 5\left(\mathrm{~kg}\right.$ mineral $\left.\mathrm{N} \mathrm{ha}^{-1} \mathrm{a}^{-1}\right)$. Variables are: $\mathrm{CV}$, Coefficient of variation; I, evaporation from interception; $\mathrm{P}$, incident precipitation; $\mathrm{SD}$, standard deviation of the differences (SD); $\mathrm{T}$, transpiration.

\begin{tabular}{|c|c|c|c|c|c|c|c|c|}
\hline & Affected Value & No (0) & N1 (60) & N2 (120) & N3 (180) & N4 (240) & Mean & $\begin{array}{l}\text { Method/Reason for } \\
\text { Neglecting }\end{array}$ \\
\hline \multicolumn{9}{|c|}{ Natural randomness } \\
\hline $\mathrm{X}_{\mathrm{N}, \mathrm{P}}$ & $\mathrm{P}$ & $6 \%$ & $6 \%$ & $6 \%$ & $6 \%$ & $6 \%$ & $6 \%$ & CV (three years) \\
\hline \multicolumn{9}{|c|}{ Input data } \\
\hline$X_{I, P}$ & $\mathrm{P}$ & $<2 \%$ & $<2 \%$ & $<2 \%$ & $<2 \%$ & $<2 \%$ & $<2 \%$ & $\begin{array}{c}\text { Assumed } \\
\text { measurement error }\end{array}$ \\
\hline$X_{N, P}+X_{I, P}$ & $\mathrm{P}$ & $8 \%$ & $8 \%$ & $8 \%$ & $8 \%$ & $8 \%$ & $8 \%$ & \\
\hline $\mathrm{X}_{\mathrm{I}, \mathrm{Y}}$ & Yield $_{\text {Seeds }}$ & $24 \%$ & $13 \%$ & $21 \%$ & $16 \%$ & $18 \%$ & $18 \%$ & $\mathrm{CV}$ \\
\hline \multicolumn{9}{|c|}{ Model parameters, Model structure } \\
\hline $\mathrm{X}_{\mathrm{M}, \mathrm{T}}$ & $\mathrm{T}$ & $45 \%$ & $45 \%$ & $45 \%$ & $45 \%$ & $45 \%$ & $45 \%$ & $\mathrm{SD}_{\mathrm{T}}{ }^{\mathrm{a}}$ \\
\hline $\mathrm{X}_{\mathrm{M}, \mathrm{I}}$ & I & $109 \%$ & $109 \%$ & $109 \%$ & $109 \%$ & $109 \%$ & $109 \%$ & $\mathrm{SD}_{\mathrm{I}}^{\mathrm{b}}$ \\
\hline
\end{tabular}

a assumed maximum $\mathrm{SD}_{\mathrm{T}}$ between modeled and measured transpiration $(\mathrm{T}) .{ }^{\mathrm{b}}$ calculated $\mathrm{SD}_{\mathrm{I}}$ between modeled and measured evaporation from interception (I).

\section{References}

1. Jagermeyr, J.; Gerten, D.; Schaphoff, S.; Heinke, J.; Lucht, W.; Rockstrom, J. Integrated crop water management might sustainably halve the global food gap. Environ. Res. Lett. 2016, 11. [CrossRef]

2. DWD Klimareport Brandenburg Climate Report Brandenburg; Deutscher Wetterdienst Offenbach/Main. 2019, p. 40. Available online: https://www.dwd.de/DE/leistungen/klimareport_bb/klimareport_bb.html (accessed on 23 April 2021).

3. Drastig, K.; Prochnow, A.; Baumecker, M.; Berg, W.; Brunsch, R. Agricultural water management in Brandenburg. Wassermanagement in der Landwirtschaft in Brandenburg. Die Erde. 2011, 142, 119-140. Available online: http:/ /www.die-erde.org/index. php/die-erde/article/download/45/40 (accessed on 23 April 2021).

4. Steidl, J.; Schuler, J.; Schubert, U.; Dietrich, O.; Zander, P. Expansion of an Existing Water Management Model for the Analysis of Opportunities and Impacts of Agricultural Irrigation under Climate Change Conditions. Water 2015, 7, 6351-6377. [CrossRef]

5. Descheemaeker, K.; Bunting, S.W.; Bindraban, P.; Muthuri, C.; Molden, D.; Beveridge, M.; van Brakel, M.; Herrero, M.; Clement, F.; Boelee, E.; et al. Increasing water productivity in agriculture. In Managing Water and Agroecosystems for Food Security; Boelee, E., Ed.; CABI: Wallingford, UK, 2013; pp. 104-123. Available online: https:/ / www.iwmi.cgiar.org/Publications/CABI_Publications/CA_ CABI_Series/Managing_Water_and_Agroecosystems/chapter_8-increasing_water_productivity_in_agriculture.pdf (accessed on 23 April 2021).

6. Bouman, B.A.M. A conceptual framework for the improvement of crop water productivity at different spatial scales. Agric. Syst. 2007, 93, 43-60. [CrossRef]

7. Perry, C.J. The IWMI water resources paradigm-definitions and implications. Agric. Water Manag. 1999, 40, 45-50. [CrossRef]

8. Davies, W.J.; Bennett, M.J. Achieving more crop per drop. Nat. Plants 2015, 1, 15118. [CrossRef]

9. Boulay, A.; Drastig, K.; Amanullah; Chapagain, A.; Charlon, V.; Civit, B.; Hess, T.; Hoekstra, A.; Ibidhi, R.; Lathuillière, M.; et al. Building consensus on water use assessment of livestock production systems and supply chains: Outcome and recommendations from the FAO LEAP Partnership. Ecol. Indic. 2021, 124, 107391. [CrossRef]

10. FAO. Water Use in Livestock Production Systems and Supply Chains-Guidelines for Assessment (Version 1). Livestock Environmental Assessment and Performance (LEAP) Partnership. Rome. 2019. Available online: http://www.fao.org/partnerships/ leap/resources/guidelines/en/ (accessed on 23 April 2021).

11. Molden, D. Accounting for Water Use and Productivity SWIM Paper 1; International Irrigation Management Institute: Colombo, Sri Lanka, 1997; Available online: http:/ / www.iwmi.cgiar.org/Publications/SWIM_Papers/PDFs/SWIM01.PDF (accessed on 23 April 2021). 
12. Prochnow, A.; Drastig, K.; Klauss, H.; Berg, W. Water use indicators at farm scale: Methodology and case study. Food Energy Secur. 2012, 1, 29-46. [CrossRef]

13. Krauss, M.; Kraatz, S.; Drastig, K.; Prochnow, A. The influence of dairy management strategies on water productivity of milk production. Agric. Water Manag. 2015, 147, 175-186. [CrossRef]

14. Krauß, M.; Keßler, J.; Prochnow, A.; Kraatz, S.; Drastig, K. Water productivity of poultry production: The influence of different broiler fattening systems. Food Energy Secur. 2015, 4, 76-85. [CrossRef]

15. Drastig, K.; Palhares, J.C.P.; Karbach, K.; Prochnow, A. Farm water productivity in broiler production: Case studies in Brazil. J. Clean. Prod. 2016, 135, 9-19. [CrossRef]

16. Van Opstal, J.; Droogers, P.; Kaune, A.; Steduto, P.; Perry, C. Guidance on Realizing Real Water Savings with Crop Water Productivity Interventions; Wageningen, FAO and FutureWater: Wageningen, The Netherlands, 2021. [CrossRef]

17. Branca, G.; Lipper, L.; McCarthy, N.; Zolejole, M.C. Food security, climate change, and sustainable land management: A review. Agron. Sustain. Dev. 2013, 33, 635-650. [CrossRef]

18. Debnath, S.; Mishra, A.; Mailapalli, D.R.; Raghuwanshi, N.S. Quantifying yield gap for rice cropping systems in Lower Gangetic Plains. Paddy Water Environ. 2018, 16, 601-615. [CrossRef]

19. Zegada-Lizarazu, W.; Monti, A. Energy crops in rotation: A review. Biomass Bioenergy 2011, 35, 12-25. [CrossRef]

20. Pena-Asín, J.P.; Costar, A.; Alvarez, A. Effect of weeding management on the performance of local maize populations. Span. J. Agric. Res. 2013, 11, 1078-1084. [CrossRef]

21. Lv, S.H.; Dong, Y.J.; Jiang, Y.; Padilla, H.; Li, J.; Uphoff, N. An opportunity for regenerative rice production: Combining plastic film cover and plant biomass mulch with no-till soil management to build soil carbon, curb nitrogen pollution, and maintain high-stable yield. Agronomy 2019, 9, 600. [CrossRef]

22. LELF Datensammlung für Die Betriebswirtschaftliche Bewertung Landwirtschaftlicher Produktionsverfahren im Land Brandenburg Ackerbau/Grünland/Tierproduktion Ausgabe 2016. Available online: https://lelf.brandenburg.de/sixcms/media.php/9/ Datensammlung\%202016_web.pdf (accessed on 23 April 2021).

23. Henke, J.; Breustedt, H.; Sieling, K.; Kage, H. Impact of uncertainty on the optimum nitrogen fertilization rate and agronomic, ecological and economic factors in an oilseed rape based crop rotation. J. Agric. Sci. 2007, 145, 455-468. [CrossRef]

24. Drastig, K.; Quiñones, T.S.; Zare, M.; Dammer, K.-H.; Prochnow, A. Rainfall interception by winter rapeseed in Brandenburg (Germany) under various nitrogen fertilization treatments. Agric. Meteorol. 2019, 268. [CrossRef]

25. Patil, B.; Lakkineni, K.; Bhargava, S. Ontogenic Changes in Growth and Assimilate Distribution as Influenced by N Supply in Rapeseed-mustard. J. Agron. Crop. Sci. 1997, 178, 15-21. [CrossRef]

26. Gu, X.-B.; Li, Y.-N.; Du, Y.-D. Effects of ridge-furrow film mulching and nitrogen fertilization on growth, seed yield and water productivity of winter oilseed rape (Brassica napus L.) in Northwestern China. Agric. Water Manag. 2018, 200, 60-70. [CrossRef]

27. Ruser, R.; Fuß, R.; Andres, M.; Hegewald, H.; Kesenheimer, K.; Köbke, S.; Räbiger, T.; Quiñones, T.S.; Augustin, J.; Christen, O. Nitrous oxide emissions from winter oilseed rape cultivation. Agric. Ecosyst. Environ. 2017, 249, 57-69. [CrossRef]

28. WRB IUSS Working Group. World Reference Base for Soil Resources 2014, Update 2015. International Soil Classification System for Naming Soils and Creating Legends for Soil Maps; World Soil Resources Reports No. 106. FAO: Rome, Italy, 2015. Available online: http: / / www.fao.org/3/i3794en/I3794en.pdf (accessed on 23 April 2021).

29. Wessolek, G.; Kaupenjohann, M.; Renger, M. Bodenphysikalische Kennwerte und Berechnungsverfahren für die Praxis. Bodenökologie und Bodengenese, 2009; Heft 40. Available online: https://www.boden.tu-berlin.de/fileadmin/fg77/_pdf/Rote_ Liste/Rote_Reihe_Heft_40.pdf (accessed on 23 April 2021).

30. Drastig, K.; Prochnow, A.; Kraatz, S.; Libra, J.; Krauß, M.; Döring, K.; Müller, D.; Hunstock, U. Modeling the water demand on farms. Adv. Geosci. 2012, 32. [CrossRef]

31. Allen, R.; Pereira, L.; Raes, D.; Smith, M. Crop Evapotranspiration-Guidelines for Computing Crop Water Requirements-FAO Irrigation and Drainage Paper 56; FAO-Food and Agriculture Organization of the United Nations: Rome, Italy, 1998; p. 297. Available online: http:/ / www.fao.org/3/X0490E/x0490e00.htm (accessed on 23 April 2021).

32. von Hoyningen-Huene, J. Die Interzeption des Niederschlages in landwirtschaftlichen Pflanzenbeständen. DVWK Schriften. 1983, 57, 1-53. Available online: https://wiki.bluemodel.org/images/9/9e/DVWK_57_I.pdf (accessed on 23 April 2021).

33. Braden, H. Ein Energiehaushalts- und Verdunstungsmodell für Wasser und Stoffhaushaltsuntersuchungen landwirtschaftlich genutzter Einzugsgebiete. Mitt. Dtsch. Bodenkdl. Ges. 1985, 42, 294-299.

34. Kutschera, L.; Lichtenegger, E.; Sobotik, M. Wurzelatlas der Kulturpflanzen Gemäßigter Gebiete mit Arten des Feldgemüsebaues; DLG-Verlag: Frankfurt am Main, Germany, 2009.

35. Döring, K.; Kraatz, S.; Prochnow, A.; Drastig, K. Indirect water demand of dairy farm buildings. Agric. Eng. Int. CIGR J. 2013, 15, 16-22. Available online: http:/ / www.cigrjournal.org/index.php/Ejounral/article/view/2726 (accessed on 23 April 2021).

36. Michelson, D.B. Systematic correction of precipitation gauge observations using analyzed meteorological variables. J. Hydrol. 2004, 290, 161-177. [CrossRef]

37. Drastig, K.; Flemming, I.; Gusovius, H.J.; Herppich, W.B. Study of Water Productivity of Industrial Hemp under Hot and Dry Conditions in Brandenburg (Germany) in the Year 2018. Water 2020, 12, 2982. [CrossRef]

38. Riar, A.; Gill, G.; McDonald, G. Different Post-Sowing Nitrogen Management Approaches Required to Improve Nitrogen and Water Use Efficiency of Canola and Mustard. Front. Plant Sci. 2020, 11, 1111. [CrossRef]

39. German Federal Statistical Office. DESTATIS Database. 2017. Available online: www.destatis.de (accessed on 22 July 2020). 
40. Wei, C.; Huang, J.; Mansaray, R.L.; Li, Z.; Liu, W.; Han, J. Estimation and mapping of winter oilseed rape LAI from high spatial resolution satellite data based on a hybrid method. Remote. Sens. 2017, 9, 488. [CrossRef]

41. Behrens, T.; Diepenbrock, W. Using digital image analysis to describe canopies of winter oilseed rape (Brassica napus L.) during vegetative developmental stages. J. Agron Crop Sc. 2006, 192, 295-302. [CrossRef]

42. Grosse, F.; Leon, J.; Diepenbrock, W. Yield formation and yield structure of winter oilseed rape (Brassica napus L.). I. Genotypic variability. J. Agron. Crop. Sci. 1992, 169, 70-93. [CrossRef]

43. Robertson, M.J.; Kirkegaard, J.A. Water-use efficiency of dryland canola in an equi-seasonal rainfall environment. Aust. J. Agric. Res. 2006, 56, 1373-1386. [CrossRef]

44. LfL. Raps: Empfehlungen zum Anbau in Brandenburg; Landesanstalt für Landwirtschaft (LfL): Potsdam, Germany, 2001.

45. Descheemaeker, K.; Amede, T.; Haileslassie, A. Improving water productivity in mixed crop-livestock farming systems of sub-Saharan Africa. Agric. Water Manag. 2010, 97, 579-586. [CrossRef]

46. Kuotsu, K.; Das, A.; Lal, R.; Munda, G.; Ghosh, P.; Ngachan, S. Land forming and tillage effects on soil properties and productivity of rainfed groundnut (Arachis hypogaea L.)-rapeseed (Brassica campestris L.) cropping system in northeastern India. Soil Tillage Res. 2014, 142, 15-24. [CrossRef]

47. Ševčíková, H.; Lhotáková, Z.; Hamet, J.; Lipavská, H. Mixotrophic in vitro cultivations: The way to go astray in plant physiology. Physiol. Plant. 2019, 167, 365-377. [CrossRef]

48. Dai, L.; Li, J.; Harmens, H.; Zheng, X.; Zhang, C. Melatonin enhances drought resistance by regulating leaf stomatal behaviour, root growth and catalase activity in two contrasting rapeseed (Brassica napus L.) genotypes. Plant Physiol. Biochem. 2020, 149, 86-95. [CrossRef] [PubMed]

49. Zhang, K.; Xing, Y.; Wang, G.; Shemi, R.; Duan, M.; Wang, L.; Xie, X. Ridge-furrow with film mulching practice ameliorates soil microbial metabolic activity and carbon utilization in rhizosphere soil of rapeseed (Brassica napus L.). J. Soils Sediments 2019, 19, 2764-2776. [CrossRef]

50. Gu, X.-B.; Li, Y.-N.; Du, Y.-D. Biodegradable film mulching improves soil temperature, moisture and seed yield of winter oilseed rape (Brassica napus L.). Soil Tillage Res. 2017, 171, 42-50. [CrossRef]

51. Feng, J.; Hussain, H.A.; Hussain, S.; Shi, C.; Cholidah, L.; Men, S.; Ke, J.; Wang, L. Optimum water and fertilizer management for better growth and resource use efficiency of rapeseed in rainy and drought seasons. Sustainability 2020, 12, 703. [CrossRef] 